\title{
Simulation of hailstorm event using Mesoscale Model MM5 with modified cloud microphysics scheme
}

\author{
P. Chatterjee ${ }^{1}$, D. Pradhan ${ }^{2}$, and U. K. De ${ }^{1}$ \\ ${ }^{1}$ School Of Environmental Studies, Jadavpur University, Jadavpur, Kolkata 700032, India \\ ${ }^{2}$ Cyclone Detection Radar, New Secretariat Building, 1 K S Roy Road, Kolkata 700001, India
}

Received: 26 April 2008 - Revised: 18 September 2008 - Accepted: 15 October 2008 - Published: 17 November 2008

\begin{abstract}
Mesoscale model MM5 (Version 3.5) with some modifications in the cloud microphysics scheme of Schultz (1995), has been used to simulate two hailstorm events over Gangetic Plain of West Bengal, India. While the first event occurred on 12 March 2003 and the hails covered four districts of the state of West Bengal, India, the second hailstorm event struck Srinikatan $\left(22.65^{\circ} \mathrm{N}, 87.7^{\circ} \mathrm{E}\right)$ on 10 April 2006 at 11:32 UT and it lasted for $2-3 \mathrm{~min}$. Both these events can be simulated, if the same modifications are introduced in the cloud microphysics scheme of Schultz. However, the original scheme of Schultz cannot simulate any hail.

The results of simulation were compared with the necessary products of Doppler Weather Radar (DWR) located at Kolkata $\left(22.57^{\circ} \mathrm{N}, 88.35^{\circ} \mathrm{E}\right)$. Model products like reflectivity, graupel and horizontal wind are compared with the corresponding products of DWR. The pattern of hail development bears good similarity between model output and observation from DWR, if necessary modifications are introduced in the model. The model output of $24 \mathrm{~h}$ accumulated rain from 03:00 UT to next day 03:00 UT has also been compared with the corresponding product of the satellite TRMM.
\end{abstract}

Keywords. Meteorology and atmospheric dynamics (Convective processes; Mesoscale meteorology; Precipitation)

\section{Introduction}

Hail is defined as precipitation in the form of ice that has a diameter of at least $5 \mathrm{~mm}$ (Rinehart, 1997). Hail usually ranges from $5 \mathrm{~mm}$ to about $10 \mathrm{~cm}$ in diameter. However, hail of higher dimension is recorded in some cases. On 14 September 1972 hail of $14 \mathrm{~cm}$ length along the higher dimension was recorded near Coffeeville, Kansas, USA. Hailstorm is regarded as a natural hazard, which causes extensive

Correspondence to: U. K. De

(deutpal2003@yahoo.com) damage to standing crop, building structure and injuries to cattle and human beings, leading sometimes to death. It is also an aviation hazard. So, effective hailwarning should be considered as a boon to any affected society. From Doppler Weather Radar (DWR) observation, it can be warned $15 \mathrm{~min}$ in advance; but modelling study is supposed to provide more advance warning, if proper parameterization can be developed for conversion of water vapour/liquid water into ice. There have been some attempts to forecast hailstorm using synoptic parametrs only (Misra and Prasad, 1980). We need clear understanding of the mechanism leading to hailstorm. From that standpoint, simulation of any hailstorm has important significance.

The meso-scale model MM5 can simulate a large variety of meteorological events across all regions of the globe. So far nearly 500 publications using the models MM4/MM5 are reported in the site of MM5 Community Model. Some of these phenomena are as diverse as, cyclone over tropical and extra-tropical regions (Patra et al., 2000; Bhaskar Rao and Hari Prasad, 2007; Srinivas et al., 2007; Sandeep et al., 2007; Davies and Bosert, 2001, 2002), severe local storm over a tropical region (Chatterjee et al., 2008), ice storm over an extra-tropical region (Noebber and Gyakum, 2003), flood over Pacific North-West (Colle and Mass, 2000), Monsoon depression (Vinod Kumar and Chandrasekhar, 2007) and wind circulation over Polar regions (Bromwich et al., 2001; Cassano et al., 2001). No work has so far been reported in the literature using the model MM5 in the simulation work of hailstorm. However, two works reporting the simulation of hailstorm have come to our notice, where two different models are used, namely, Garcia-Ortega et al. (2007) and Buckley et al. (2001).

We show here that the hailstorm event can still be simulated with the help of the model MM5, provided the cloud microphysics scheme of Schultz (1995) is modified suitably. This becomes necessary to create hail as the cloud microphysics part involves the parameterization for the conversion

Published by Copernicus Publications on behalf of the European Geosciences Union. 
of water vapour/liquid into ice. The same modified scheme has been used in the simulation of two different hailstorms in the Gangetic Plain of West Bengal, India.

\section{Tools being used}

\subsection{Description of MM5 model}

Penn State University, US and National Center for Atmospheric Research (NCAR), US developed mesoscale model MM5 Version 3.5 (Grell et al., 1994) has been used which is non-hydrostatic in nature and has terrain following 23 vertical sigma coordinates. Final analysis data from the global model output of National Centers for Environmental Prediction (NCEP) with $1^{\circ} \times 1^{\circ}$ grid resolution has been used as initial and boundary values. United States Geographic System (USGS) based vegetation, land-use and topography are used in this model. Model can incorporate meteorological observational data as input during the model run. It has both one-way as well as two-way nesting facility.

The present authors have noted from their previous studies (Chatterjee et al., 2008) that, the following combination of schemes of different physical processes gives the closest simulation for severe local storms in the region under consideration:

- Cloud Microphysics or explicit moisture scheme Schultz (1995)

- Cumulus parameterization - Grell (1993)

- Planetary Boundary layer process - MRF (Hong and Pang, 1996)

- Land surface process - 5 layer soil model (Dudhia 1996)

- Radiation - Cloud radiation scheme

- Convection - Absence of shallow convection, by default in the model

\subsection{Doppler weather radar}

DWR is being used worldwide for the study of different severe weather phenomena like thunderstorm, hailstorm, tornado and cyclone. Doppler radar has a great potential to enhance the capabilities of researchers and scientists to estimate the intensity of precipitation in the cloud on real time basis, apart from helping to keep a close watch on its movement. It is capable of producing various derived products from three basic products viz. Reflectivity (Z), Radial Component of Velocity (V) and Spectrum width (W). Doviak et al. (1979), and Wilson and Wilk (1982) concluded that the radial wind information obtained from a single DWR can be used to derive and estimate, the horizontal wind, wind shear and other products useful for the study of weather events. Radial velocity products provide an estimate of both horizontal and vertical wind shear. Spectrum width indicates turbulence associated with the storm. The DWR at Kolkata $\left(22.57^{\circ} \mathrm{N}\right.$, $88.35^{\circ} \mathrm{E}$ ) has a beam width of 1 degree and nominal range of about $450 \mathrm{~km}$ for reflectivity and $250 \mathrm{~km}$ for radial velocity as well as spectrum width. Maximum unambiguous radial velocity estimates following unfolding techniques is about $64 \mathrm{~m} / \mathrm{s}$ (approximately $220 \mathrm{~km} / \mathrm{h}$ ) with a radial resolution of $1 \mathrm{~km}$ and 1 degree in azimuth. Reflectivity products are mainly used for the study of severe weather phenomena. Radial velocity products provide many useful information about the weather phenomena, like horizontal and vertical shears (HZS and VCS), an estimate of prevailing wind speed and its direction (PPI_V), a vertical profile of the horizontal wind from $0.3 \mathrm{~km}$ to $7.5 \mathrm{~km}$ over the DWR within an area of $40 \mathrm{~km}$ radius (VVP_2).

Mention must be made of another DWR product, namely hail warning information HHW, which has been utilized in the present study. This information is generated, when the radar reflectivity lies between 45 and $55 \mathrm{dBZ}$ within the altitude of 5 to $10 \mathrm{Km}$ (Gematronik, 1997). Usually the height of freezing level is close to $5 \mathrm{Km}$ and super cooled droplets are supposed to remain suspended above that height. When these droplets come in contact with ice pellets supposed to be formed around different nuclei, graupels start to grow because of riming. The graupels may remain suspended in air for quite long time due to strong updraft in a thundercloud. The graupels within the altitude $5-10 \mathrm{Km}$ have good chance of falling down on the ground as hail. When the reflectivity is $45-50 \mathrm{dBZ}$ within that altitude, the hail is highly probable (denoted by yellow colour in DWR plot), and if the reflectivity is $50-55 \mathrm{dBZ}$, the hail is said to be probable (denoted by red colour in DWR plot).

In this paper, analysis of some severe weather events is done using Doppler Weather Radar that may be useful for intensive research in understanding the structure of the severe weather events.

\section{Methodology and data}

Meso-scale model MM5 is being run with the mother domain having a grid resolution of $90 \mathrm{~km}$. By first and second nesting i.e. by scaling down, the resolution of the domain of study has been improved to $10 \mathrm{Km}$ (Fig. 1). The choice of schemes for different physical processes is already mentioned in Sect. 2.1. However, this particular choice of simulation cannot create a storm with hail. To do that, attempt has been made to modify the cloud-microphysics scheme of Schultz.

In Schultz scheme there are five categories of condensate, which include cloud liquid $(c)$ with zero fall velocity, cloud ice $(p)$, rain $(r)$, snow $(s)$ and precipitating ice $(i)$. The last case includes graupel, sleet, and hail. The four processes, 
Table 1. Changes of controlling parameters in different processes in Schultz microphysics scheme.

\begin{tabular}{lccccc}
\hline Conversion rate control parameter & $\begin{array}{c}\text { Diffusional crystal growth } \\
\text { parameter }\left(C_{v p}\right)\end{array}$ & $\begin{array}{c}\text { Riming of ice } \\
\text { parameter }\left(C_{c i}\right)\end{array}$ & $\begin{array}{c}\text { Freezing rain } \\
\text { parameter }\left(C_{r i}\right)\end{array}$ & $\begin{array}{c}\text { Melting snow } \\
\text { parameter }\left(C_{s r}\right)\end{array}$ & $\begin{array}{c}\text { Melting ice } \\
\text { parameter }\left(C_{i r}\right)\end{array}$ \\
\hline Original Cloud Microphysics values & 25.0 & 16.7 & $8.33 \mathrm{E}-6$ & $8.33 \mathrm{E}-6$ & $1.67 \mathrm{E}-6$ \\
Modified Cloud Microphysics Values & 35.0 & 18.5 & $9.33 \mathrm{E}-6$ & $6.33 \mathrm{E}-6$ & $0.17 \mathrm{E}-6$ \\
\hline
\end{tabular}

like, condensation and glaciation, collection, melting, and evaporation are included in the formation of precipitating ice.

In glaciation process, ice crystals are first nucleated in vapour environment supersaturated with respect to ice at a temperature below $-20^{\circ} \mathrm{C}$. Then the crystals grow by vapour diffusion. The diffusional crystal growth rate is given by

$\partial q_{p} / \partial t=C_{v p}\left(q_{v}-q_{i s}\right) q_{p}$,

where $C_{v p}$ is the conversion rate control parameter, $q_{p}$ is ice crystal specific mass, $q_{v}$ is water vapour specific mass and $q_{i s}$ is saturation vapour specific mass with respected to water in liquid phase.

The growth of graupel by riming process results from collection of supercooled liquid by graupel and the growth rate is given by

$\partial q_{i} / \partial t=C_{c i} q_{i} q_{c}$,

where $C_{c i}$ is the conversion rate control parameter, $q_{i}$ is precipitating ice specific mass and $q_{c}$ is cloud liquid specific mass.

There is another collection process, called riming snow and the rate of formation is similar in form like the previous equation, but is given by a separate control parameter. The formation of ice by freezing of rain is another important process for the formation of ice and is given by,

$\partial q_{i} / \partial t=C_{r i}(265-T)^{2}$

where $C_{r i}$ is the rate control parameter.

It has been assumed here that cloud ice and snow melt immediately on attaining the melting point (Dudhia, 1989), but ice can fall a considerable distance through the warmer air.

For snow the melting rate is

$\partial r_{s} / \partial t=-C_{s r}(T-273.1)$

where $C_{s r}$ is conversion rate control parameter and $r_{s}$ is precipitating snow mixing ratio.

For ice, the melting rate is

$\partial r_{i} / \partial t=-C_{i r}(T-273.1)$,

where $C_{i r}$ is conversion rate control parameter and $r_{i}$ is precipitating ice mixing ratio.

In order to simulate a hailstorm over Gangetic West Bengal Region, it is necessary to modify some of the above mentioned processes by optimizing their rates. The values of all

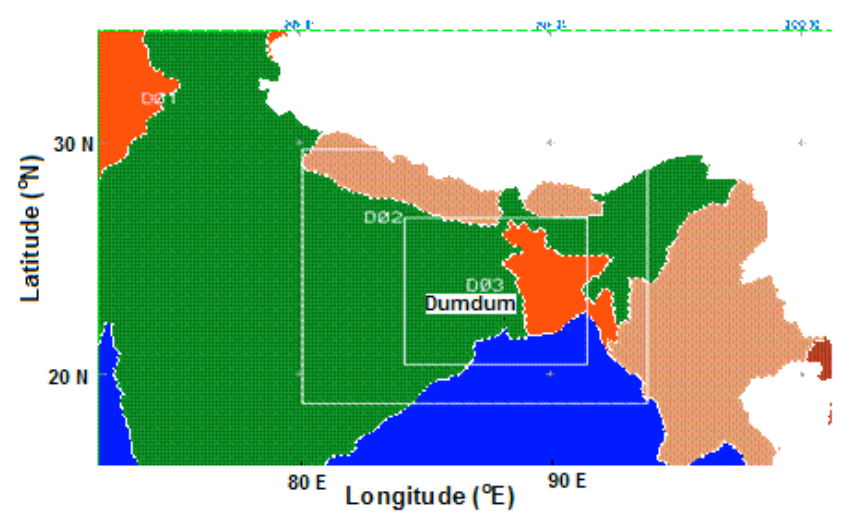

Fig. 1. Model domains with the innermost one being the domain of study.

the changed control parameters are shown in Table 1. In original Shultz scheme, the diffusional crystal growth is found to be slow for this region and so it has been enhanced. The change of value of the control parameter from 25 to 35 , certainly helps in the growth of ice in the cloud. The enhancement in the value of two of the next three control parameters causes further growth of ice in the cloud. The riming ice parameter is enhanced slightly and this helps in enhancing the collection capability of graupel. The control parameter for riming snow is sufficiently high in Schultz scheme and is left unaltered. The high value is justified by the fact that snow has higher density and so, a larger surface area for the same mass. This means, snow has higher collection capability. The freezing rain parameter is enhanced slightly by optimizing the situation.

On the loss side, the melting rate in Schultz scheme is sufficiently high for a tropical environment and the precipitating ice cannot reach the ground through air warmer than the melting point. So the rate of melting for snow as well as ice has been reduced here.

To run the MM5 model, Vegetation, Landuse, Soil, Terrain etc of USGS have been used. NCEP final analysis (fnl) data of $1^{\circ} \times 1^{\circ}$ resolution is used as initial and boundary condition. To improve the initial and boundary conditions of the model, surface observation data over the domain were collected from India Meteorological Department (IMD) and Data Service Section (DSS), NCAR and also RS/RW data of DSS, NCAR were utilized in the model. To verify the model output, 
Doppler Radar products from the DWR, Kolkata and rainfall data of the satellite, Tropical Rainfall Measuring Mission (TRMM) have been used.

\section{Hailstorm cases}

In the present study only two hailstorm events have been taken up. The first one occurred on 12 March 2003. The thunderstorm associated with hail had a wind speed of 16$20 \mathrm{~m} / \mathrm{s}$ and it affected four districts of the state of West Bengal, India, namely Bankura, Hooghly, Howrah and South 24-Paraganas. Two wind squalls were reported by India Meteorological Department (IMD) to strike Dumdum $\left(22.65^{\circ} \mathrm{N}\right.$, $88.45^{\circ} \mathrm{E}$ ), Kolkata. While the first one struck at 08:55 UT and lasted for one minute only, the second one struck at 11:14 UT and it lasted for one minute. The maximum wind speed rose to $21 \mathrm{~m} / \mathrm{s}$ and $23 \mathrm{~m} / \mathrm{s}$ in two respective cases. Among the observatories of IMD in the state, maximum rainfall was reported at Dumdum and it was $78.7 \mathrm{~mm}$ within the period 08:40 UT to 22:35 UT. Hailstorm was reported to last at Diamond Harbour (22.25 N, 88.67 E) of 24-Paraganas district for $22 \mathrm{~min}$, though the hail size was not so significant. The system was quite severe in the other three districts and the death toll reported by different agencies went up to 30 people: 3 in Bankura, 23 in Hooghly and 4 in Howrah. Apart from that, more than 500 people were injured. The associated hailstorm caused significant infrastructure damages. In the Hooghly district alone, 31277 hutments collapsed fully and 35000 structures were partially damaged. In the Bankura district, the corresponding tolls were 6852 and 23953 , respectively. The maximum hail size was reported $3 \mathrm{~cm}$ in Bankura district, but the corresponding magnitude is not available for Hoogly district.

The second hailstorm case being considered here was reported by IMD to strike Srinikatan $\left(23.65^{\circ} \mathrm{N}, 87.7^{\circ} \mathrm{E}\right)$ on 10 April 2006 at 11:32 UT and it lasted for 2-3 min. The maximum diameter of hail was noted as $2 \mathrm{~cm}$. A wind squall occurred at Malda $\left(25.03^{\circ} \mathrm{N}, 88.13^{\circ} \mathrm{E}\right)$ from easterly direction with maximum wind speed of $15.28 \mathrm{~m} / \mathrm{s}$ at 20:02 UT on that day and it lasted for $3 \mathrm{~min}$. Highest maximum temperature in the region was reported at Jamshedpur $\left(22.49^{\circ} \mathrm{N}, 86.11^{\circ} \mathrm{E}\right)$ and it was $44^{\circ} \mathrm{C}$. Among the IMD observatories located over the Gangetic West Bengal, only Srinikatan $\left(23.65^{\circ} \mathrm{N}\right.$, $87.7^{\circ} \mathrm{E}$ ) experienced $24 \mathrm{~h}$ accumulated rainfall of $20 \mathrm{~mm}$ at 03:00 UT on 11 April. Maldah $\left(25.03^{\circ} \mathrm{N}, 88.13^{\circ} \mathrm{E}\right)$ experienced only a trace rainfall in the same period.

\section{Results and discussions}

The zone of present study is confined to the domain after second nesting in the model (Fig. 1). Model simulated 24$\mathrm{h}$ accumulated rainfall was compared with TRMM rainfall product 3B42(V6). For the case of 12 March 2003, TRMM data show two sharp peaks of $70 \mathrm{~mm}$ rain, one is close to
Dumdum $\left(22.65^{\circ} \mathrm{N}, 88.45^{\circ} \mathrm{E}\right)$, whereas the other is close to Bankura $\left(23.15^{\circ} \mathrm{N}, 87.03^{\circ} \mathrm{E}\right)$ town (Fig. 2a). The model with by-default microphysics scheme shows good number of patches of $100 \mathrm{~mm}$ rain and it can capture the distribution in the central part of the domain, though there is over prediction in general (Fig. 2b). The model produces heavy rain in North Bengal as well as North Bangladesh, which is absent in TRMM data. On the other hand, it cannot reproduce the rain in the east of the domain. The distribution pattern of 24$\mathrm{h}$ accumulated rain is almost identical in by-default as well as modified cloud microphysics model, though more precipitation occurs in some places in the latter case (Fig. 2c). It appears, the model with modified microphysics scheme produces more rain in general.

TRMM rainfall picture for 10 April 2006 shows heavy rainfall over sub Himalayan regions of West Bengal and Assam. A local peak of $20 \mathrm{~mm}$ rain is found near Srinikatan $\left(23.65^{\circ} \mathrm{N}, 87.7^{\circ} \mathrm{E}\right)$, as one can find from Fig. 2d. In case of the model with either by-default or modified microphysics scheme, the major rain-band shifts to the south (Fig. 2e and f). The rain-band produces more rain in many places and in case of modified scheme, the rain is surely more copious. Thus, we can conclude that, though the rainfall distribution pattern is almost the same in both the models, the one with modified scheme gives more rain. If compared with TRMM observations, the models have limited success. In one case, the major distribution in the central part of the domain is captured, though the models produce rain in some other places as well. In the other case, the observed rain-band is shifted southwards. Location of different landmarks stated in this work is shown in Fig. 3.

Model simulated horizontal wind may be compared with Radar product PPI(V). Figure 4a is PPI(V) plot at 11:01 UT on 12 March 2003, which shows high wind of $15 \mathrm{~m} / \mathrm{s}$ near Goghat $\left(22.43^{\circ} \mathrm{N}, 87.87^{\circ} \mathrm{E}\right)$, Kalyani $\left(22.98^{\circ} \mathrm{N}, 88.48^{\circ} \mathrm{E}\right)$, Jamshedpur $\left(22.49^{\circ} \mathrm{N}, 86.11^{\circ} \mathrm{E}\right)$ and Tangail $\left(24.25^{\circ} \mathrm{N}\right.$, $89.92^{\circ} \mathrm{E}$ ) in Bangladesh. Model with default microphysics simulates at 11:06 UT a maximum horizontal wind of value $12 \mathrm{~m} / \mathrm{s}$ at one location only as shown in Fig. $4 b$, whereas, the model with modified microphysics can attain a maximum wind of $14 \mathrm{~m} / \mathrm{s}$ along with wind of $12 \mathrm{~m} / \mathrm{s}$ at a number of places as shown in Fig. 4c.

In case of 10 April 2006, the radar product PPI(V) of 11:48 UT shows one sharp peak of value more than $16 \mathrm{~m} / \mathrm{s}$ near Burdwan $\left(23.23^{\circ} \mathrm{N}, 87.85^{\circ} \mathrm{E}\right)$ and high wind patch over Sundarban region of West Bengal as shown in Fig. 4d. Model, with both microphysics options, can simulate at 11:51 UT a similar peak wind of $15 \mathrm{~m} / \mathrm{s}$ as shown in Fig. 4e and $\mathrm{f}$. In both the simulations, the location of high wind has a spatial shift, compared to the observation. However, near the Sunderban region, both the models show an enhanced patch of wind.

Model product reflectivity (dBZ) has been compared with Doppler Radar product Max(Z) (in dBZ). Fig. 5a, which is $\operatorname{MAX}(\mathrm{Z})$ product at 10:18 UT on 12 March 2003, shows 
(a)

TRMM 3日42(V6) 03:00 UT 12 Mar. 2003 to 03:00 UT 13 Mar. 2003

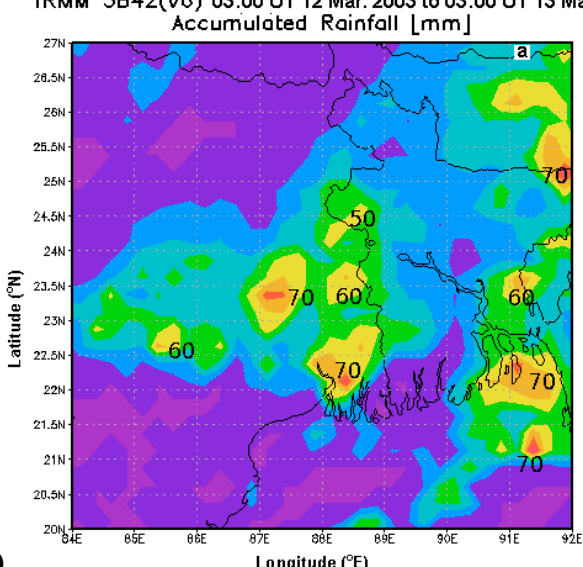

24 hour accumulated rain (mm) from 03:00 UT 12 Mar. 2003 to 03:00 UT 13 Mar. 2003

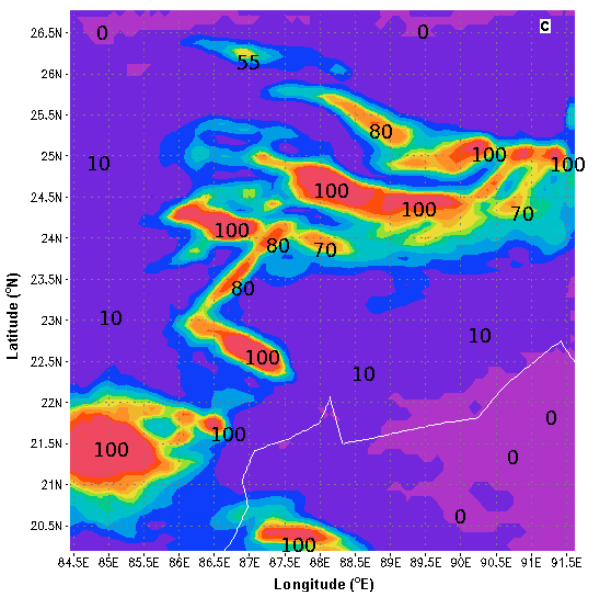

(c)

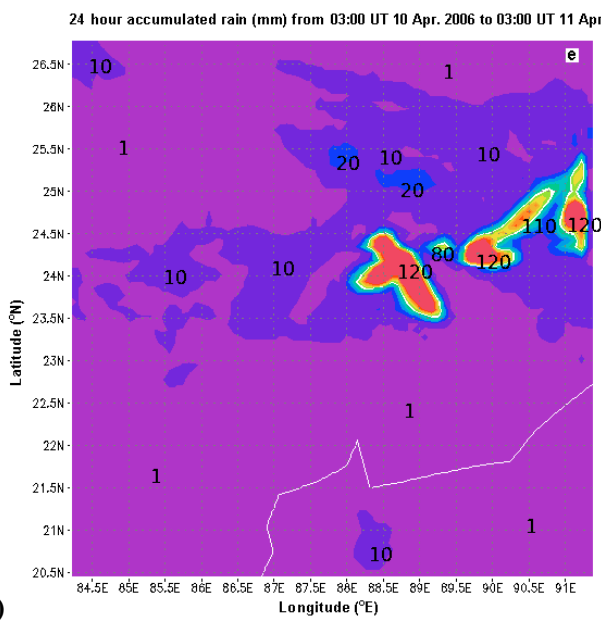

(b)

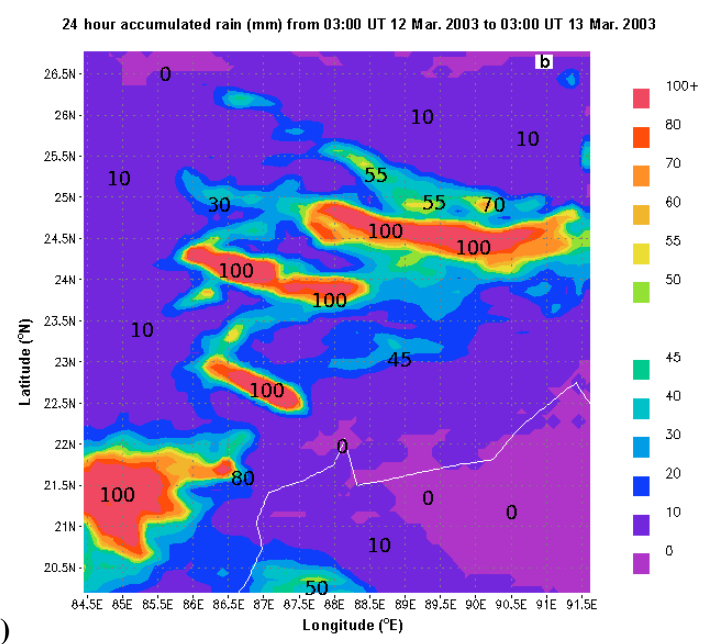

TRMM 3B42(V6) 03:00 UT 10 Apr. 2006 to 03:00 UT 11 Apr. 2006

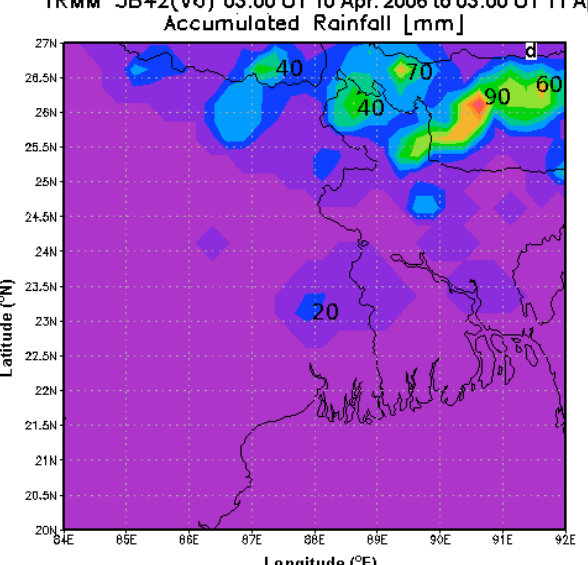

(d)
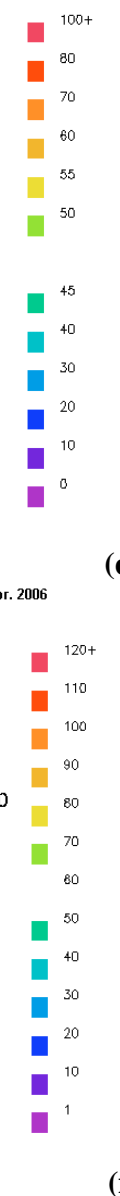

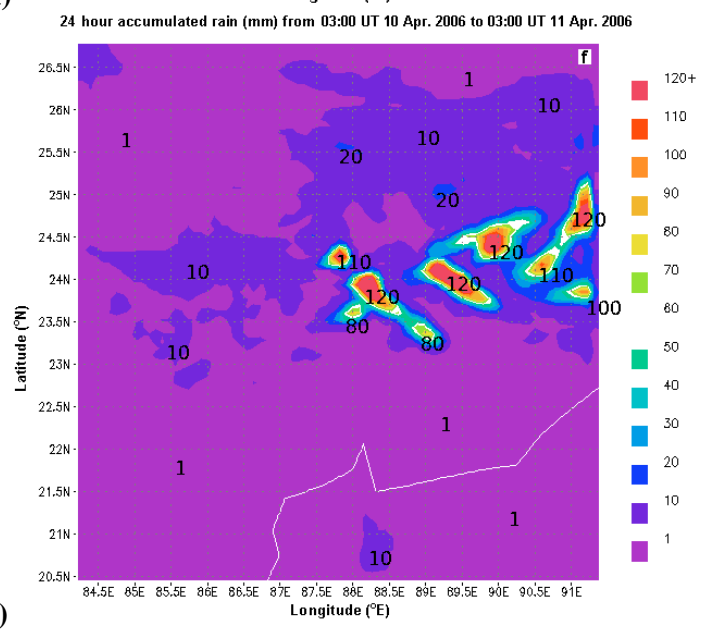

Fig. 2. (a) TRMM 24-h rainfall (03:00 UT, 12 March 2003 to 03:00 UT, 13 March 2003). (b) Model derived 24-h rainfall with default cloud microphysics (03:00 UT, 12 March 2003 to 03:00 UT, 13 March 2003). (c) Model derived 24-h rainfall with modified cloud microphysics (03:00 UT, 12 March 2003 to 03:00 UT, 13 March 2003). (d) TRMM 24-h rainfall (03:00 UT, 10 April 2006 to 03:00 UT, 11 April 2006). (e) Model derived 24-h rainfall with default cloud microphysics (03:00 UT, 10 April 2006 to 03:00 UT, 11 April 2006). (f) Model derived 24-h rainfall with modified cloud microphysics (03:00 UT, 10 April 2006 to 03:00 UT, 11 April 2006). 


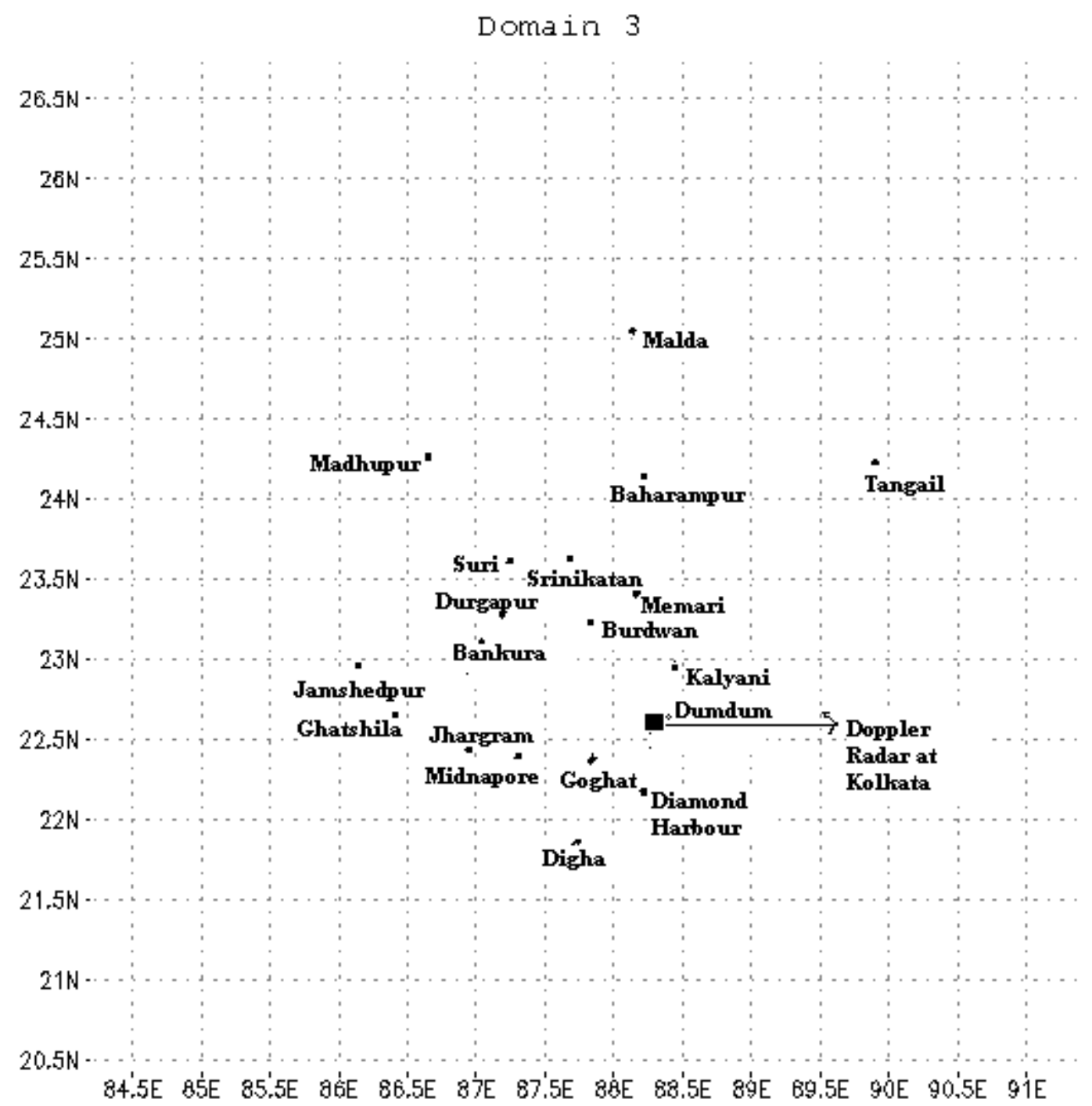

Fig. 3. Various landmarks stated in this work.

three echoes above $45 \mathrm{dBZ}$, the one with $60 \mathrm{dBZ}$ intensity is close to Ghatshila $\left(22.60^{\circ} \mathrm{N}, 86.48^{\circ} \mathrm{E}\right)$, the one with $55 \mathrm{dBZ}$ intensity is near Dumdum and another with $55 \mathrm{dBZ}$ is close to Midnapore $\left(22.41^{\circ} \mathrm{N}, 87.31^{\circ} \mathrm{E}\right)$. Model simulated reflectivity at 10:21 UT, both with default and modified microphysics, show a number of cloud patches having echo of $50 \mathrm{dBZ}$ intensity as shown in Fig. 5b and c, respectively. In both the simulations, one echo is found to be close to Dumdum. $\operatorname{MAX}(Z)$ plot at 11:18 UT shows three major echoes of value 55 to $60+\mathrm{dBZ}$, near Purulia $\left(23.20^{\circ} \mathrm{N}, 86.25^{\circ} \mathrm{E}\right)$, Midnapore $\left(22.41^{\circ} \mathrm{N}, 87.31^{\circ} \mathrm{E}\right)$ and Dumdum $\left(22.65^{\circ} \mathrm{N}, 88.45^{\circ} \mathrm{E}\right)$, respectively, as shown in Fig. 5d. Figure 5e and $\mathrm{f}$ is model simulated reflectivity at 11:15 UT, with two previously used microphysics schemes. In Fig. 5e, we find five sharp cloud patches with reflectivity of $55 \mathrm{dBZ}$ to $60 \mathrm{dBZ}$, whereas it reduces to three such patches in Fig. 5f. This shows that the modified cloud microphysics scheme gives the reflectivity pattern close to reality. However, in all the cases, there is some spatial mismatch.

For 10 April 2006 hailstorm case, Fig. 6a shows MAX(Z) plot at 09:18 UT, where one can observe one major echo of intensity $60 \mathrm{dBZ}$ near Dumka $\left(24.26^{\circ} \mathrm{N}, 87.25^{\circ} \mathrm{E}\right)$, along with some others of smaller height. Figure $6 \mathrm{~b}$ and $\mathrm{c}$ shows model reflectivity at 09:18 UT with default and modified microphysics schemes respectively. From these figures one can say that the model, with modified microphysics, simulates one strong echo of $60 \mathrm{dBZ}$ near Baharampur $\left(24.13^{\circ} \mathrm{N}\right.$, $88.26^{\circ} \mathrm{E}$ ); whereas the model with default microphysics, cannot simulate any such intense echo at all. Figure $6 \mathrm{~d}$ shows $\operatorname{MAX}(\mathrm{Z})$ plot at 10:18 UT, where four strong echoes are found, aligned almost linearly near $\operatorname{Suri}\left(23.58^{\circ} \mathrm{N}, 87.32^{\circ} \mathrm{E}\right)$. Model, with modified microphysics, shows one strong echo of $60 \mathrm{dBZ}$ along with two other echoes of near $40 \mathrm{dBZ}$ close to Baharampur $\left(24.13^{\circ} \mathrm{N}, 88.26^{\circ} \mathrm{E}\right)$ as shown in Fig. 6f; 
(a)
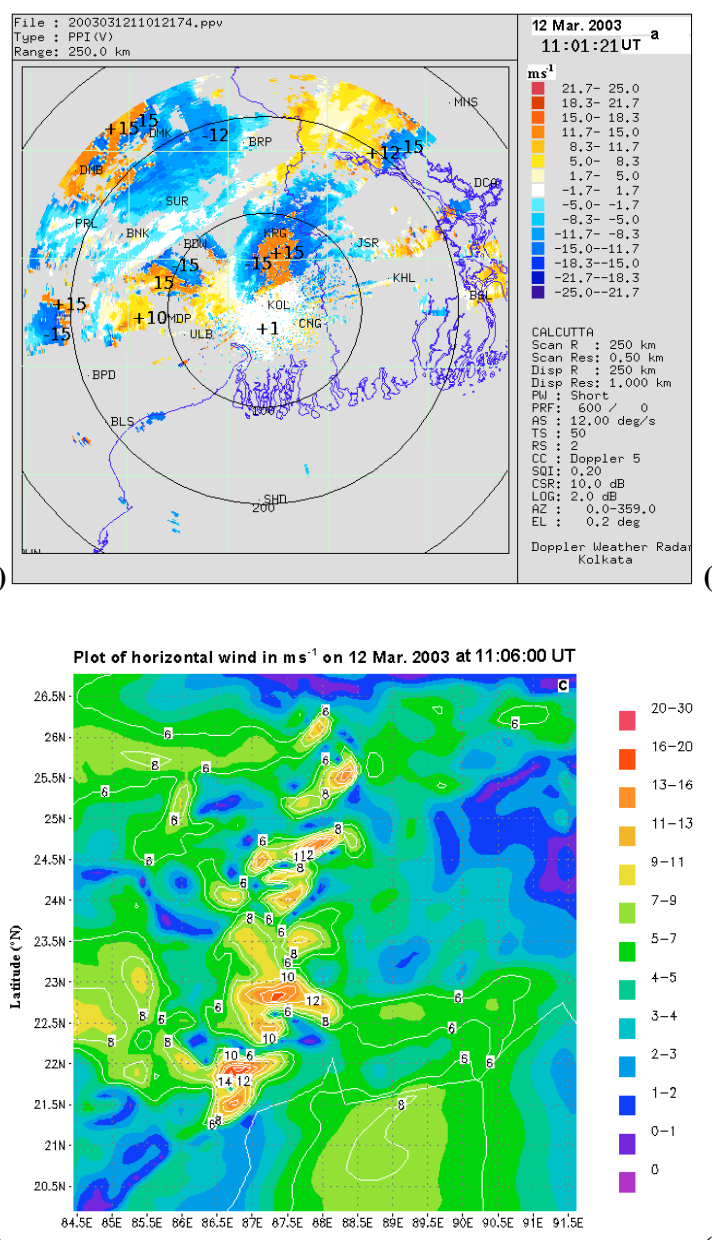

(c)

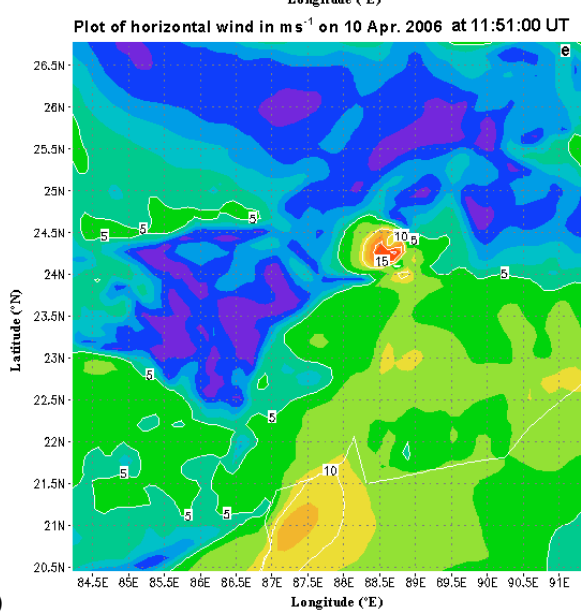

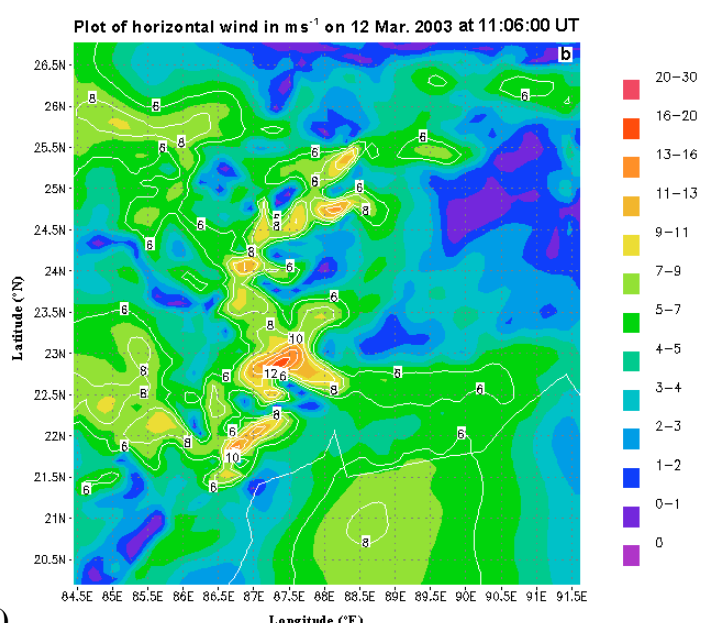

(b)

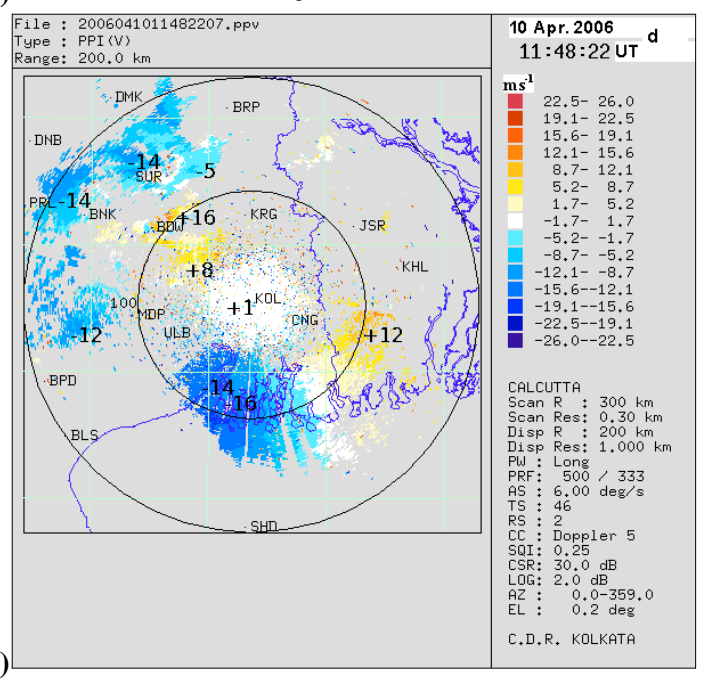

(d)

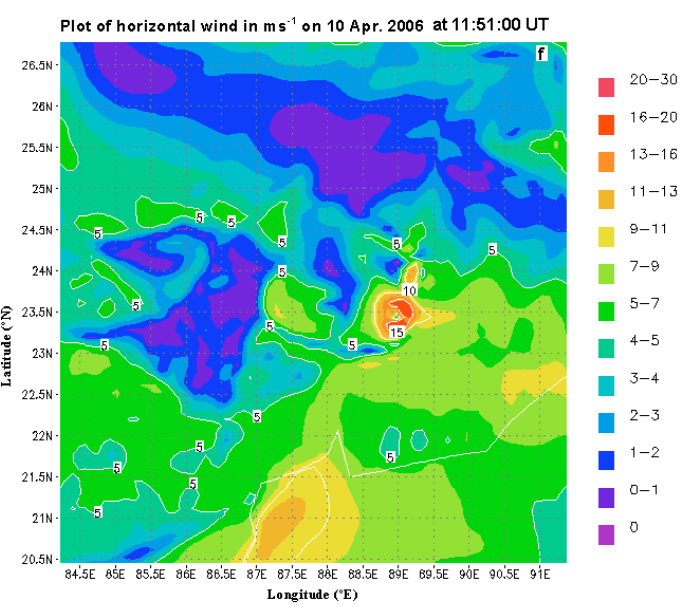

Fig. 4. (a) DWR derived wind PPI(V) at 11:01 UT, 12 March 2003. (b) Model simulated wind with default microphysics scheme at 11:06 UT, 12 March 2003. (c) Model simulated wind with modified microphysics at 11:06 UT, 12 March 2003. (d) DWR derived wind PPI(V) at 11:48 UT, 10 April 2006. (e) Model simulated wind with default microphysics scheme at 11:51 UT, 10 April 2006. (f) Model simulated wind with modified microphysics scheme at 11:51 UT, 10 April 2006. 
(a)
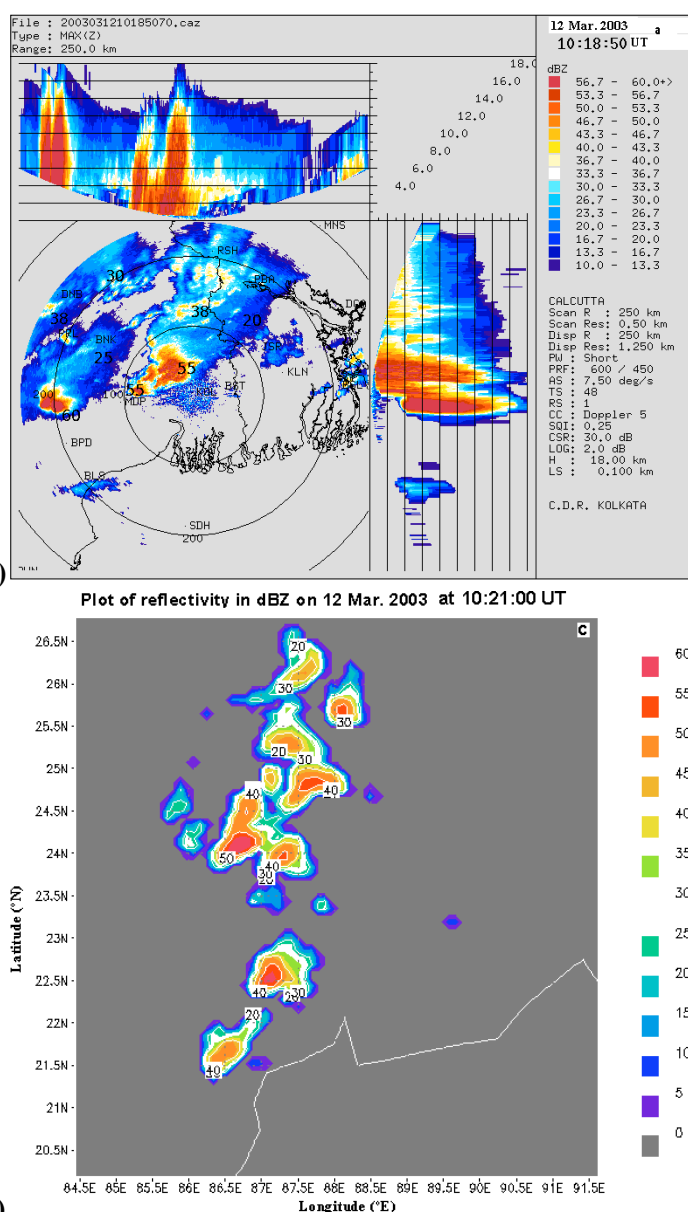

(c)

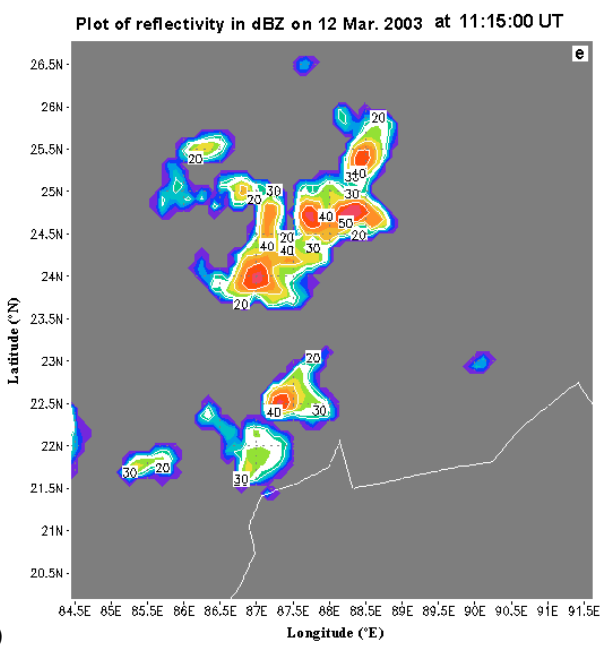

(e)

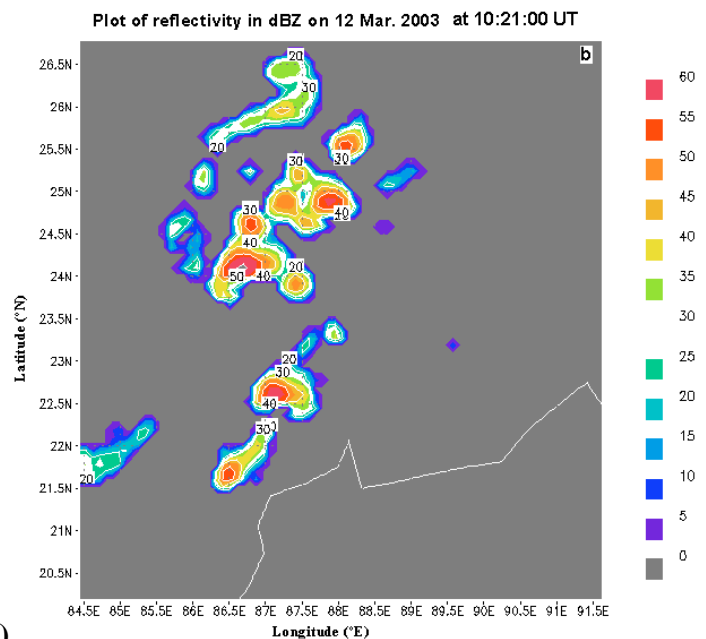

(b)

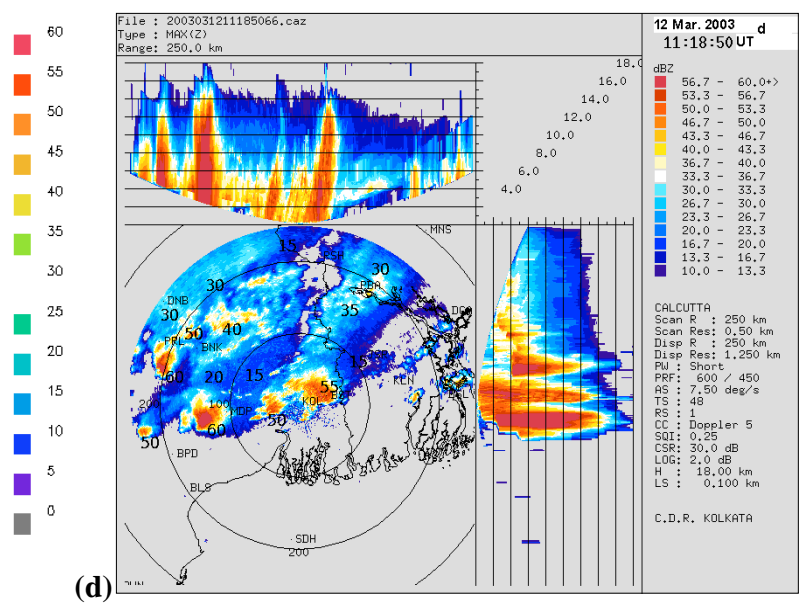

(d)

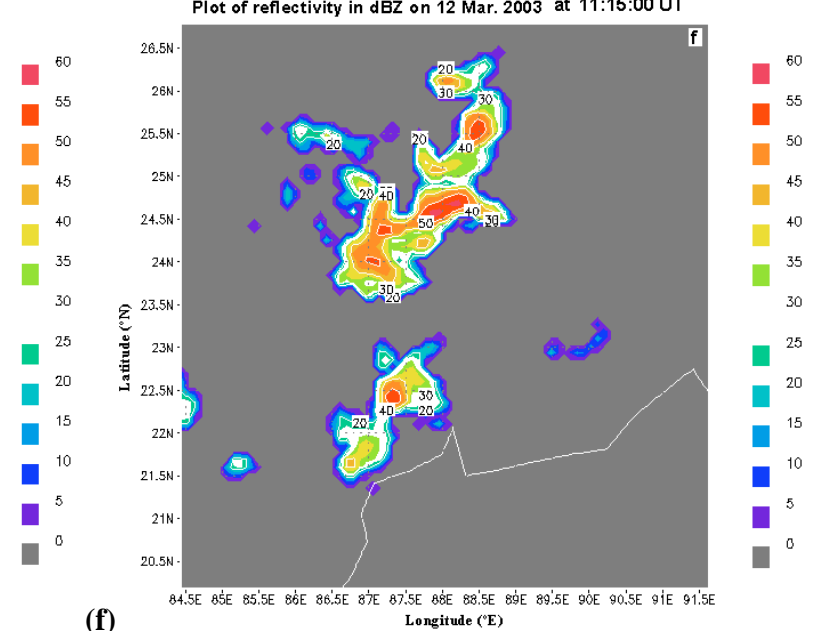

(f)

Longitude ( $(\mathrm{E})$

Fig. 5. (a) DWR derived reflectivity $\operatorname{Max}(\mathrm{Z})$ at 10:18 UT, 12 March 2003. (b) Model simulated reflectivity with default cloud microphysics at 10:21 UT, 12 March 2003. (c) Model simulated reflectivity with modified cloud microphysics at 10:21 UT, 12 March 2003. (d) DWR derived reflectivity $\operatorname{Max}(\mathrm{Z})$ at 11:18 UT, 12 March 2003. (e) Model simulated reflectivity with default cloud microphysics at 11:15 UT, 12 March 2003. (f) Model simulated reflectivity with modified cloud microphysics at 11:15 UT, 12 March 2003. 
(a)

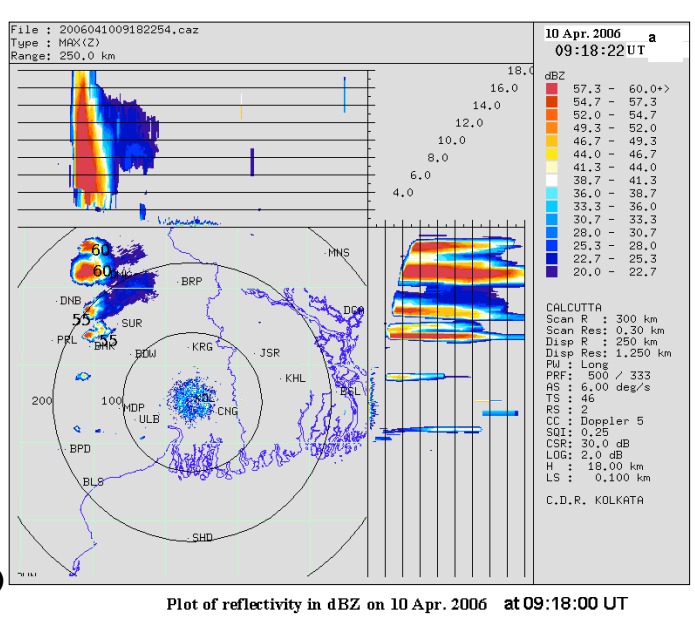

(c)

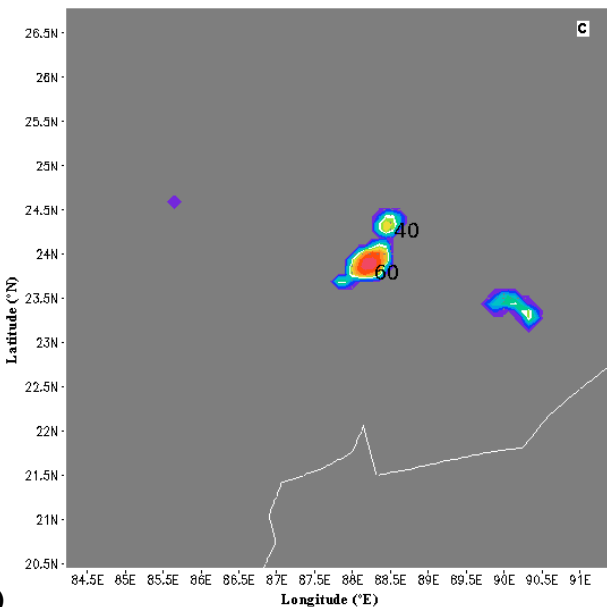

Plot of reflectivity in dBZ on $10 \mathrm{Apr}$. 2006 at 10:21:00 UT

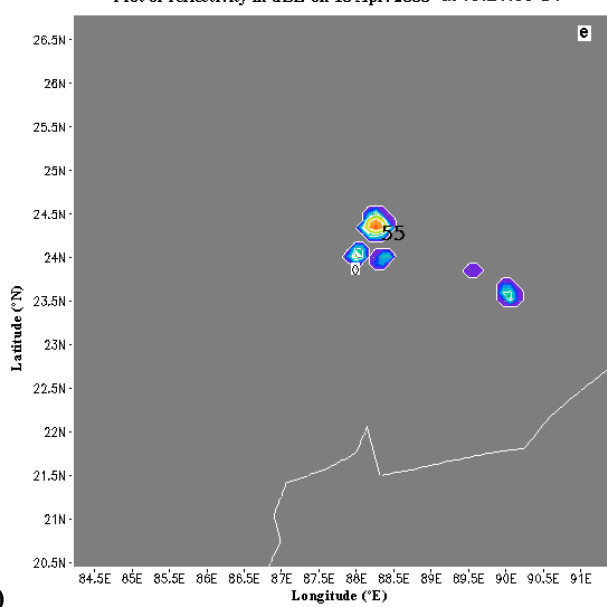

(b)

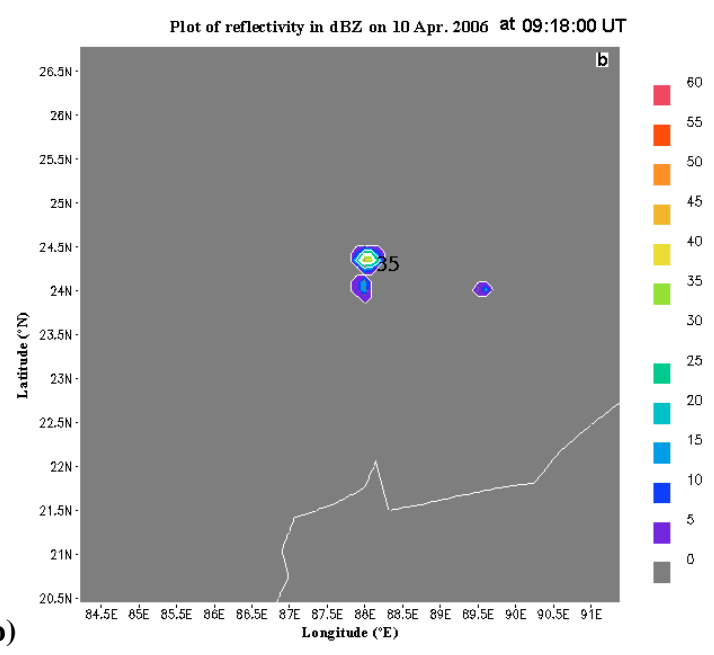

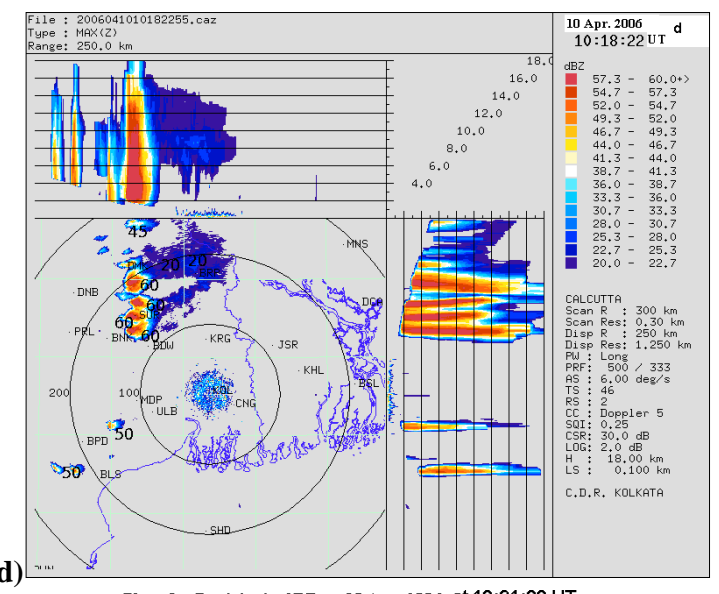

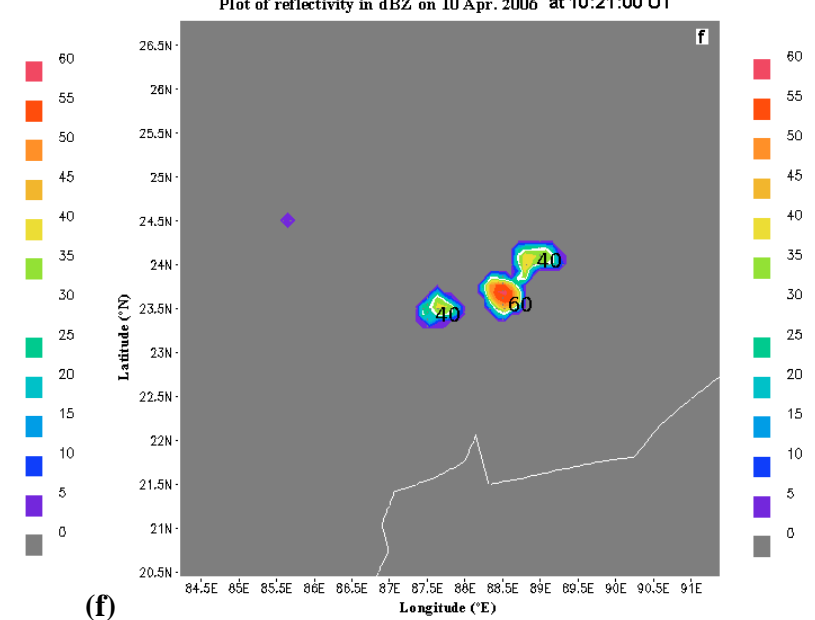

Fig. 6. (a) DWR derived reflectivity $\operatorname{Max}(\mathrm{Z})$ at 09:18 UT, 10 April 2006. (b) Model simulated reflectivity with default cloud microphysics at 09:18 UT, 10 April 2006. (c) Model simulated reflectivity with modified cloud microphysics at 09:18 UT, 10 April 2006. (d) DWR derived reflectivity $\operatorname{Max}(Z)$ at 10:18 UT, 10 April 2006. (e) Model simulated reflectivity with default cloud microphysics at 10:21 UT, 10 April 2006. (f) Model simulated reflectivity with modified cloud microphysics at 10:21 UT, 10 April 2006. 


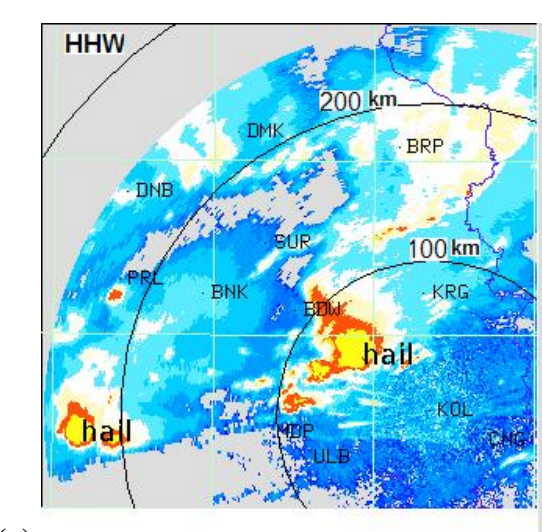

(a)

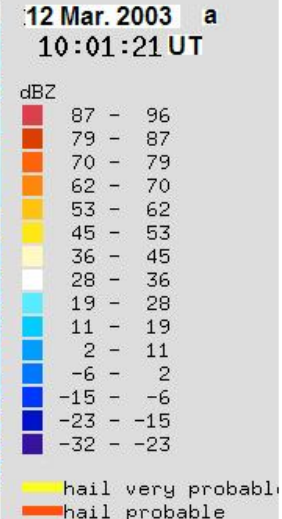

hail probable (b)

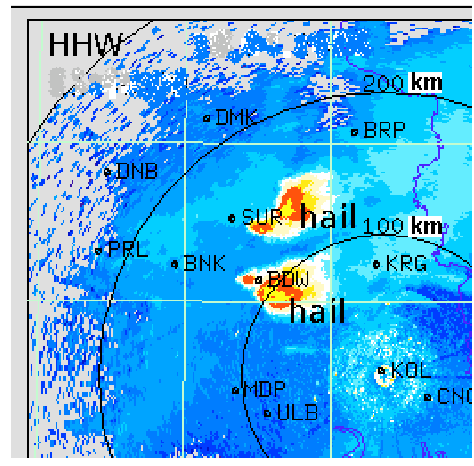

(c)

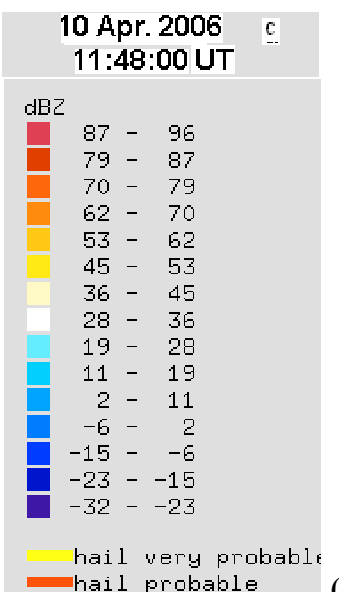

10 Apr. 2006 $\mathrm{dB} 2$

hail probable

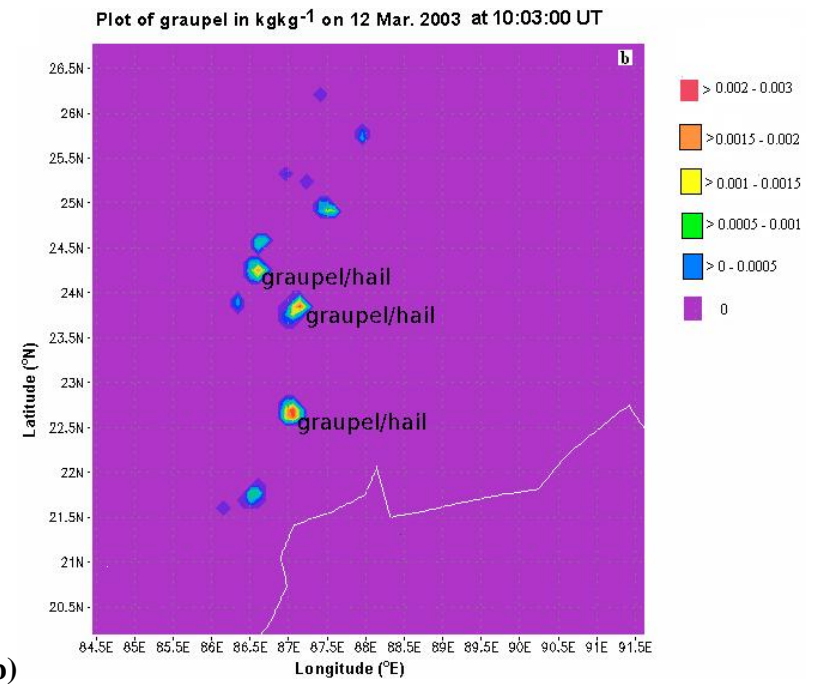

(b)

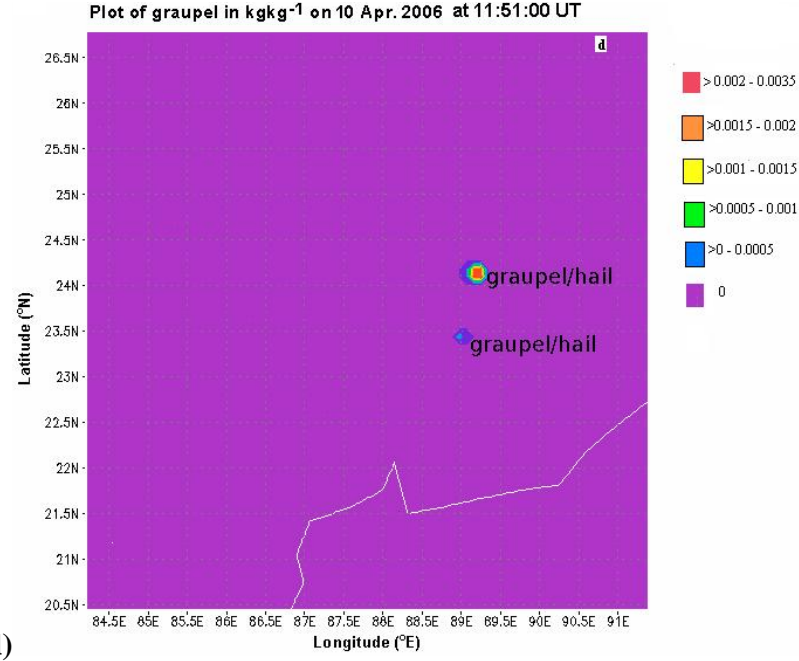

Fig. 7. (a) DWR derived hail warning product HHW at 10:01 UT, 12 March 2003. (b) Model simulated graupel with modified cloud microphysics at 10:03 UT, 12 March 2003. (c) DWR derived hail warning product HHW at 11:48 UT, 10 April 2006. (d) Model simulated graupel with modified cloud microphysics at 11:51 UT, 10 April 2006.

whereas the model with default microphysics, simulates only one major peak of maximum value $55 \mathrm{dBZ}$ near Malda $\left(25.03^{\circ} \mathrm{N}, 88.13^{\circ} \mathrm{E}\right)$ as shown in Fig. 6e. So, from the above analysis one can say that, only the model with modified microphysics scheme can simulate intense echo as observed by the Doppler Radar.

Doppler radar hail warning product HHW is being utilized for comparison with the model product graupel. In the 12 March 2003 case, HHW at 10:01 UT shows two highly probable large regions of hailstorm, along with another smaller region close by. The largest region is located at Memari $\left(23.46^{\circ} \mathrm{N}, 88.11^{\circ} \mathrm{E}\right)$ and the second region is close to Ghatshila $\left(22.60^{\circ} \mathrm{E}, 86.48^{\circ} \mathrm{N}\right)$ as shown in Fig. 7a. Model with modified microphysics simulates three peaks of graupel on the ground at 10:03 UT, the most dominant one occurs at Jhargram $\left(22.45^{\circ} \mathrm{N}, 86.98^{\circ} \mathrm{E}\right)$. So the most intense zone of hailstorm in the model simulation is shifted to the southwest from the actual location. The other two occur at Durgapur $\left(23.30^{\circ} \mathrm{N}, 87.20^{\circ} \mathrm{E}\right)$ and Madhupur $\left(24.25^{\circ} \mathrm{N}, 86.65^{\circ} \mathrm{E}\right)$ as shown in Fig. 7b. The maximum mixing ratio of graupel in this case is $3 \mathrm{~g} / \mathrm{kg}$, so the upper limit of colour code in Fig. 7b is taken at that value. The above mentioned two places are supposed to be the most probable regions of hailstorm. When the model is simulated with default microphysics at 10:03 UT, no graupel is observed at any place.

For 10 April 2006 hailstorm case, HHW plot at 11:48 UT shows two very probable spots for hailstorm, one is close to Suri $\left(23.58^{\circ} \mathrm{N}, 87.32^{\circ} \mathrm{E}\right)$ and the other near Burdwan $\left(23.23^{\circ} \mathrm{N}, 87.85^{\circ} \mathrm{E}\right)$ as one can see from Fig. $7 \mathrm{c}$. Model with default microphysics scheme cannot simulate any graupel anywhere in the domain at 11:51 UT. The simulation of graupel on the ground with modified microphysics is presented 
in Fig. 7d. The maximum value of graupel mixing ratio in this case is $3.5 \mathrm{~g} / \mathrm{kg}$, accordingly the upper limit in the colour code is chosen. There are two peaks in Fig. 7d; the major one is located close to Pubna $\left(24.2^{\circ} \mathrm{N}, 89.2^{\circ} \mathrm{E}\right)$, Bangladesh and the other is also in Bangladesh at $\left(23.5^{\circ} \mathrm{N}, 89.0^{\circ} \mathrm{E}\right)$. So, there has been eastward shift of the zone of activity.

From the above study, one can infer that the model MM5 has the ability to simulate hailstorm if the cloud microphysics scheme of Schultz is modified, though there exists spatial shift in occurrence.

\section{Conclusions}

So far no work is reported in the literature regarding simulation of hail with the help of mesoscale model MM5. However, the present authors find that the model MM5 has the ability to simulate hailstorm if the cloud-microphysics scheme of Schultz is modified suitably. The proposed modification not only can simulate hail, but also improves the reflectivity pattern, enhances $24-\mathrm{h}$ accumulated rain as well as wind at many places. In all cases, however, discrepancy occurs in the location of the event.

Acknowledgements. The authors thank India Meteorological Department for the supply of Doppler Weather Radar data. Thanks are due to S. K. Ghosh, Retired Deputy Director General of Meteorology, IMD for going through the manuscript and making valuable suggestions. One of the authors (UKD) thanks the Department of Science \& Technology, Government of India for the sanction of a research project and the present work forms a part of that project.

Topical Editor F. D'Andrea thanks E. Garcia-Ortega and another anonymous referee for their help in evaluating this paper.

\section{References}

Bhaskar Rao, D. V. and Hari Prasad, D.: Sensitivity of tropical cyclone intensification to boundary layer and convective processes, Nat. Hazards, 41, 429-445, 2007.

Buckley, B. W., Leslie, L. M., and Wang, Y.: The Sydney hailstorm of April 14, 1999: Synoptic description and numerical simulation, Met. Atmos. Phys., 76, 167-182, 2001.

Bromwich, D. H., Cassano, J. J., Klein, T., Heinemann, G., Hines, K. M., Staffen, K., and Box, J. E.: Mesoscale modeling of Katabatic winds over Greenland with polar MM5, Mon. Weather Rev., 129, 2290-2309, 2001.

Cassano, J. J., Box, J. E., Bromwich, D. H., Li, L., and Staffen, K.: Evaluation of polar MM5 simulations of Greenland's atmospheric circulation, J. Geophys. Phys., 106, 33 867-33 890, 2001.

Chatterjee, P., Pradhan, D., and De, U. K.: Simulation of severe local storm by Mesoscale Model MM5, Indian J. Rad. Space Phys., 37(6), in press, 2008.

Colle, B. A. and Mass, C. F.: The 5-9 February 1996 flooding event over the Pacific North-West : Sensitivity studies and evaluation of the MM5 precipitation forecasts, Mon. Weather Rev., 128, 593-617, 2000.
Davies, C. A. and Bosert, L. F.: Numerical simulation of the genesis of hurricane Diana (1984) Part I: Control simulation, Mon. Weather Rev., 129, 1859-1881, 2001.

Davies, C. A. and Bosert, L. F.: Numerical simulation of the genesis of hurricane Diana (1984) Part II: Sensitivity to track and intensity prediction, Mon. Weather Rev., 130, 1100-1124, 2002.

Doviak, R. J., Zrnic, D. S., and Sirmans, D. S.: Doppler Weather Radar, Proceedings of IEEE, 67(11), 1522-1553, 1979.

Dudhia, J.: Numerical study of convection observed during the Winter Monsoon Experiment using a mesoscale two dimensional model, J. Atmos. Sci., 46, 3077-3107, 1989.

Dudhia, J.: A multi-layer soil temperature model for MM5, 6th Annual MM5 Users' Workshop, Boulder, USA, 1996.

Garcia-Ortega, E., Fita, L., Romero, R., Lopez, L., Ramis, C., and Sanchez, J. L.: Numerical simulation and sensitivity study of a severe hailstorm in north-east Spain, Atmos. Res., 83, 225-241, 2007.

Gematronik, Germany: Rainbow Operator's Manual, Version 3.4, 2, 107-108, 1997.

Grell, G. A.: Prognostic evaluation of assumptions used by cumulus parameterizations, Mon. Weather Rev., 121, 764-787, 1993.

Grell, G. A., Dudhia, J., and Stauffer, D. R.: A description of the 5th generation Penn State/ NCAR Mesoscale Model (MM5), NCAR Tech. NCAR/TN, pp. 398+138, 1995.

Hong, S. and Pan, H.: Nonlocal boundary layer vertical diffusion in a medium range forecast model, Mon. Weather Rev., 124, 23222339, 1996.

Misra, P. K. and Prasad, S. K.: Forecasting hailstorm over India, Mausam, 31, 385-396, 1980.

Noebber, P. J. and Gyakum, J. R.: Orographic influences on the mesoscale structure of the 1998 ice storm, Mon. Weather Rev., 131, 27-50, 2003.

Patra, P. K., Santhanam, M. S., Potty, K. V. J., Tewari, M., and Rao, P. L. S.: Simulation of tropical cyclones using regional weather prediction models, Current Sci., 79, 70-78, 2000.

Rinehart, R. E.: Radar for Meteorologists, Rinehart Publications, Grand Forks, ND, USA, 152-154, 1997.

Sandeep, S., Chandrasekhar, A., and Dash, S. K.: On the prediction of tropical cyclones over the Indian region using a synthetic vortex scheme in a mesoscale model, Pure Appl. Geophys., 164, 1443-1463, 2007.

Schultz, P.: An explicit cloud physics parameterization for operational numerical weather prediction, Mon. Weather Rev., 123, 3331-3343, 1995.

Srinivas, C. V., Venkatesan, R., Bhaskar Rao, D. V., and Hari Prasad, D.: Numerical simulation of Andhra severe cyclone (2003): model sensitivity to the boundary layer and convective parameterization, Pure Appl. Geophys. (India), 164, On-line publication, 2007.

Vinod Kumar and Chandrasekhar, A.: Ensemble lagged forecasts of a monsoon depression over India using a mesoscale model, Atmosfera, 20, 25-44, 2007.

Wilson, J. W. and Wilk, K. E.: Nowcasting applications of Doppler Radar, Nowcasting, edited by: Browning, K., Academic Press, London, 87-105, 1982. 